\title{
PERSISTENCE OF MALACHITE GREEN IN TISSUES OF RAINBOW TROUT AFTER A LONG-TERM THERAPEUTIC BATH
}

\author{
J. MÁCHOVÁ ${ }^{\prime \prime}$, Z. SVOBODOVÁ ${ }^{1,2)}$, J. SVOBODNÍK(', V. PIAČKA ${ }^{2)}$, B. VYKUSOVÁ ${ }^{1}$, A. KOCOVÁ ${ }^{1)}$ \\ ${ }^{1}$ Research Institute of Fish Culture and Hydrobiology, University of South Bohemia, Vodñany") University of \\ Veterinary and Pharmaceutical Sciences, Brno ${ }^{3)}$ ECOLAB Lid., Znojmo
}

Received March 23, 1996

Accepted June 6, 1996

\begin{abstract}
Máchová J., Z. Svobodová, J. Svobodník. V. Piačka, B. Vykusová, A. Kocová: Persistence of Malachite Green in Tissues of Rainbow Trout After a long-tern Therapeutic Bath. Acta vet. Brno 1996, 65:151-159.

The goal of this paper was to test the time of malachite green persistence in rainbow trout after long-term bath as well as to evaluate the quality of randomly sampled marketable rainbow trout from the point of view of malachite green residues. A 6-day-lasting therapeutic bath of rainbow trout was performed in malachite green of $0.2 \mathrm{mg} . \mathrm{l}^{-1}$ concentration. Its residues were then observed in muscle, liver and skin of treated fish. Immediately after the bath. malachite green was detected in muscle, liver and skin at the levels of $0.712 \pm 0.383,0.83+$ and $0.649 \mathrm{mg} \cdot \mathrm{kg}^{-1}$. respectively, as a sum of both coloured form and leukoform. Eight weeks after the bath, an expressive decrease of the coloured form of malachite green was found while its leukoform was detected in fish as late as after 10 months. Results of analyses were found negative twelve months after the bath. Marketable rainbow trout were randomly sampled for checking the malachite green content on 12 trout farms in the Czech Republic in 1993-1995. Malachite green was found in 2 case (in 1 of them only as a slightly increased value in skin) while all other findings were negative. Hence, the results of our study indicate that malachite green persisted in the treated fish as a leukoform for 10 months. It was evident that the 6-months withdrawal time. recommended in the Czech Republic was insufficient. In case of the frequent one-and-half-year-long productive cycle of rainbow trout we therefore do not recommend to carry out therapeutic baths in malachite green for fish older than 6 months.
\end{abstract}

Malachite green, Oncorhynchus mykiss, theraperatic bath, residues, withdrancal time

The application of malachite green in fisheries is a long discussed problem. Its fungicidal effects have been known since 1930's (Foster and Woodbury 1936). During the 1950 s, malachite green had been used as antiseptic in medicine, as well as a remedy against both external and internal parasites. In $1960{ }^{\circ} \mathrm{s}$, malachite green has appeared to be the most effective remedy against unicellular ciliate ectoparasites. i.e. namely against Ichthyophthirius multifilis. Its importance was enhanced after a discovery of its effectiveness against fungus Saprolegnia sp. on eggs. This was how malachite green became consequently one of the most frequently used preparations in fisheries. A large number of data in literature (e.g. Lucký 1978; Jeney et al. 1979; Scott 1982: Alderman 1985: Antychowicz and Rogulska 1985; Bastiawan 1986: Vykusová and Svobodová 1986; Clifton-Hadley and Alderman 1987: Eimen 1989; Rydlo 1990; Alderman and Clifton-Hadley 1993: Noga 1995 a.o.) also document its broad use in commercial fisheries.

On the other hand, negative effects of malachite green cannot be set aside, namely its high toxicity for fish (Lanzing 1965: Willford 1966: Máchová and Svobodová 1984), as well as the side effects of this preparation to the treated fish. Ke $y$ l and Werth (1959) proved in their experiments with cyprinids that a $0.1 \mathrm{mg} . \mathrm{l}^{-1}$ concentration induced a cytopathic syndrome in experimental fish. Studnicka et al. (1975) proved an unfavourable effect of this preparation on mitotic activity of gill epithelium cells and 
degenerative alterations in gill epithelium. Other data on negative effects of malachite green on fish were reported by Steffens et al. (1961), Řehulka (1977), Sumari et al. (1979), Eimen (1989) and others.

Its carcinogenic, mutagenic and teratogenic effects found in insects (Ke yl and Werth 1959), rainbow trout and rats (Meyer and Jorgenson 1983) make another very important aspect which must be taken into account during its use. Werth (1958) firstly advised upon the danger of human health impairment. This author also described an expressive increase in number of internal tumours in rats to which malachite green has been administered. Furthermore, W e r th (1958) also described occurrence of defective progeny up to the 9th generation in rats after oral administration of the substance. Meyer and J o r g en s on (1983) also described impairments of skeleton, heart, kidney and liver in rats as a consequence of malachite green application.

Moreover. it was proved that it has a great affinity to animal tissues (Bauer et al. 1988). It means under practical conditions that during a bath of fish in malachite green this preparation is expressively cumulated in fish body. B a u e r et al. (1988) reports that $90 \%$ of malachite green accepted is cumulated in muscle as a leukobasis (reduced uncoloured form). While the coloured form is eliminated quickly, leukobasis is eliminating very slowly. This is the reason why application of malachite green in some countries is permitted only for treatment of ornamental fish. Negative effects of malachite green including persistence of its residues reflected in great effort to substitute this substance by another more safe preparation ( Bailey 1984; Schmahl etal. 1989; Rapp 1995; Schmidt et al. 1995; Svobodová et al. 1995).

The hygienic limit of malachite green content in the Federal Republic of Germany is determined as $10 \mu \mathrm{g} \cdot \mathrm{kg}^{-1}$ fish muscle (E i m e n 1989). In the Czech Republic there has been no hygienic limit for malachite green content determined yet, nevertheless there are regulations to adhere to a 6-months withdrawal time since the fish bath till their market distribution.

In available literature there are data on the rate of malachite green elimination from fish tissues after short-term therapeutic baths. The data refer to very slow elimination of this substance from fish body (B auer et al. 1988). A long-term (6 days) therapeutic bath in malachite green is used very frequently in rainbow trout culture. It is therefore questionable if a 6-months withdrawal time is sufficient after such long-term baths. The paper presented reports data on observation of malachite green persistence in tissues of rainbow trout subjected to 6-days bath in malachite green. Moreover, it reports results of random sampling of marketable rainbow trout for checking the malachite green content in their tissues, carried out on 12 trout farms in the Czech Republic in 1993-1995.

\section{Materials and Methods}

Marketable rainbow trout obtained from a fish farming facility of Trout Farm Annín were subjected to 6-days therapeutic bath of malachite green in concentration of $0.2 \mathrm{mg} \cdot \mathrm{l}^{-1}$. Malachite green used for the bath was J 3 ESA (ICA firm), imported from Italy. Therapeutic bath was initiated on July 14 and finished on July 20, 1993. Bath was performed in 2001 aquaria stocked with 45 rainbow trout of $203.6 \pm 40.3$ g mean body mass. Fish were daily transferred to freshly prepared therapeutic bath. Control group of fish (not treated) was kept in identical conditions to experimental fish treated with the therapeutic bath and daily transferred to clean water without any malachite green addition. Water temperature in both experimental and control aquaria ranged between $12-14^{\circ} \mathrm{C}$. Immediately after termination of the bath, 5 fish of the control group and $15 \mathrm{fish}$ of the experimental group were sampled, weighed and muscle, skin and liver samples were taken for determination of malachite green content. Two "blended" samples of muscle were taken from fish of the control group. i.e. from 2 and from 3 fish. while "blended" sample of skin and/or liver was taken from 5 fish. Seven "blended" samples of muscle were taken from fish of the experimental group, i.e. from 2 and/or 3 fish each, while one "blended" sample of skin and/or liver was taken from 15 fish. Samples were stored in microtene bags, frozen to $-18^{\circ} \mathrm{C}$ and sent for analyses. 
The remaining fish were marked and transported back to the fish culture facility at Annin where they were kept in a separate storage pond similarly to other fish stocks. Samples of these fish were weighed at regular time intervals; samples for checking the malachite green content were taken in chosen time intervals. Malachite green content was determined immediately after the bath, 8 weeks afterwards, and then after the 6-months withdrawal time since the fish bath was performed till their market distribution which was to be fulfilled according to valid regulations in the Czech Republic. Further control sampling and analyses were performed as long as malachite green residues were detected in experimental fish. Data on sampling times, samples taken and results of analyses are given in Table 1.

For checking the food hygiene quality of marketable rainbow trout from the point of view of malachite green content, random sampling was also performed. Samples of muscle, skin and liver of rainbow trout obtained from 5 and 7 trout farms were taken in 1993 and 1995, respectively. Eight to fifteen marketable rainbow trout were taken from every fish farm and "blended" samples of muscle, skin and/or liver were analyzed. In total, 142 fish were sampled, ranging in weight from $150 \mathrm{~g}$ to $595 \mathrm{~g}$ (mean body mass $286 \pm 67.8 \mathrm{~g}$ ).

Analyses of malachite green content were performed by means of high-pressure liquid chromatography after extraction, purification of extract and oxidation of the uncoloured leukoform according to B a ue r et al. (1988). This approach allowed to register both the content of coloured form of malachite green in fish samples and its total content (a sum of coloured form and uncoloured leukoform).

\section{Results}

Malachite green residues in rainbow trout treated with therapeutic bath

The total content of malachite green in muscle, liver and skin of rainbow trout immediately after treatment by a long-term bath in malachite green ranged in $0.368-2.750 \mathrm{mg} \cdot \mathrm{kg}^{-1}$ (Table 1). It is evident that at that time the share of coloured form of malachite green reached $34 \%$ in muscle, $30.3 \%$ in liver and $58.5 \%$ in skin samples (Fig. 1).

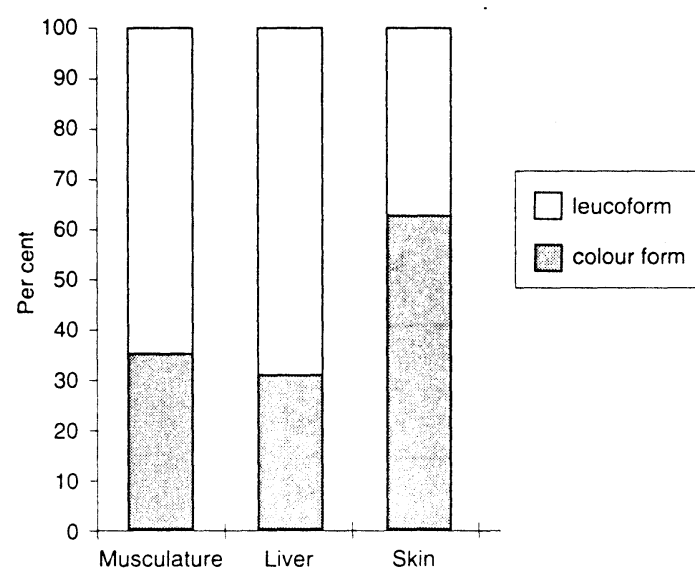

Fig. 1: Rate of coloured form and leukoform of malachite green in tissue samples of rainbow trout taken immediately after a 6-day therapeutic bath.

Analyses carried out during the following period proved a significant decrease of coloured form of malachite green. Eight weeks after the bath, coloured form of malachite green was detected in skin only: $0.011 \mathrm{mg} \cdot \mathrm{kg}^{-1}$, referring to about $1 \%$ of its total content. Its content in other samples, i.e. in muscle and liver was beyond the limit of detection. During the next checking (i.e. in 6 months after the bath), coloured form of malachite green was detected only in 2 of 7 muscle samples analyzed, in amount of 0.01 $\mathrm{mg} \cdot \mathrm{kg}^{-1}$.

On the other hand, the decrease expressed as a sum of malachite green was very slow. Its mean value in muscle samples taken 8 weeks after the bath was even higher than that immediately after the bath. However, the difference was not significant. Statistically significant decrease of malachite green content in muscle of the treated fish was proved after 6 months. The subsequent decrease of malachite green content in fish muscle was very slow again; this was evidenced also by the fact that differences among mean values from consequent samplings were not significant (Table 1). Malachite green expressed as a sum of malachite green was still detected in fish tissues 7 months after the bath. In eight months after the bath the analyses performed were still positive, except for 
Table 1

Malachite green content in muscle, liver and skin of rainbow trout after a 6-days bath

\begin{tabular}{|c|c|c|c|c|c|}
\hline \multirow[t]{2}{*}{$\begin{array}{l}\text { Sampling } \\
\text { Date }\end{array}$} & \multirow[t]{2}{*}{$\begin{array}{l}\text { Time After } \\
\text { Bath }\end{array}$} & \multirow[t]{2}{*}{$\begin{array}{l}\text { Tissue } \\
\text { Sample Data }\end{array}$} & \multicolumn{2}{|c|}{ Sum of $\frac{\text { Coloured Form }}{\text { Malachite Green }}$} & \multirow{2}{*}{$\begin{array}{l}\text { Statistical } \\
\text { Significance } \\
\text { of Difference } \\
\text { at } P<0.05\end{array}$} \\
\hline & & & $\begin{array}{l}x \pm s_{g_{1}} \\
(\mathrm{mg} \cdot \mathrm{kg})\end{array}$ & $\begin{array}{l}\min -\max \\
\left(\operatorname{mg} \cdot \mathrm{kg}^{-1}\right)\end{array}$ & \\
\hline \multirow[t]{3}{*}{20.7 .93} & \multirow[t]{3}{*}{$\begin{array}{l}\text { immediately } \\
\text { after bath }\end{array}$} & $\begin{array}{l}\text { ouscle } \\
7 \text { blended samples } \\
\text { of } 15 \mathrm{fish}\end{array}$ & $\frac{0.2421 \pm 0.2918}{0.7121 \pm 0.3826}$ & $\frac{0.022-0.843}{0.368-2.090}$ & \multirow[t]{3}{*}{$<$} \\
\hline & & $\begin{array}{l}\text { liver } \\
1 \text { blended sample } \\
\text { of } 15 \mathrm{fish}\end{array}$ & $\frac{0.834}{2.750}$ & & \\
\hline & & $\begin{array}{l}\text { skin } \\
1 \text { blended sample } \\
\text { of } 15 \mathrm{fish}\end{array}$ & $\frac{0.649}{1.110}$ & & \\
\hline \multirow[t]{3}{*}{13.9 .93} & \multirow[t]{3}{*}{$\begin{array}{l}8 \text { weeks } \\
\text { after bath }\end{array}$} & $\begin{array}{l}\text { muscle } \\
7 \text { blended samples } \\
\text { of } 14 \mathrm{fish}\end{array}$ & $\frac{<0.001}{0.9800 \pm 0.2285}$ & $0.491-1.160$ & \\
\hline & & $\begin{array}{l}\text { liver } \\
1 \text { blended sample } \\
\text { of } 14 \mathrm{fish}\end{array}$ & $\begin{array}{l}\text { insufficient } \\
\text { sample }\end{array}$ & & \\
\hline & & $\begin{array}{l}\text { skin } \\
1 \text { blended sample } \\
\text { of } 14 \mathrm{fish}\end{array}$ & $\frac{0.011}{1.600}$ & & \\
\hline \multirow[t]{3}{*}{7.1 .94} & \multirow[t]{3}{*}{$\begin{array}{l}6 \text { months } \\
\text { after bath }\end{array}$} & $\begin{array}{l}\text { muscle } \\
7 \text { samples } \\
\text { of } 7 \text { fish }\end{array}$ & $\begin{array}{l}\text { in } 2 \text { samples } \underline{0.01} \\
0.0604 \pm 0.02267\end{array}$ & $0.021-0.088$ & \multirow[t]{3}{*}{$<<$} \\
\hline & & $\begin{array}{l}\text { liver } \\
1 \text { blended sample } \\
\text { of } 7 \text { fish }\end{array}$ & $\begin{array}{l}\text { insufficient } \\
\text { sample }\end{array}$ & & \\
\hline & & $\begin{array}{l}\text { skin } \\
1 \text { blended sample } \\
\text { of } 7 \text { fish }\end{array}$ & $\frac{0.009}{0.030}$ & & \\
\hline \multirow[t]{3}{*}{9.2 .94} & \multirow[t]{3}{*}{$\begin{array}{l}7 \text { months } \\
\text { after bath }\end{array}$} & $\begin{array}{l}\text { muscle } \\
7 \text { samples } \\
\text { of } 7 \text { fish }\end{array}$ & $\frac{\leq 0.001}{0.0464 \pm 0.0402}$ & $0.012-0.122$ & \multirow[t]{3}{*}{$<-$} \\
\hline & & $\begin{array}{l}\text { liver } \\
1 \text { blended sample } \\
\text { of } 7 \text { fish }\end{array}$ & $\frac{<0.001}{0.006}$ & & \\
\hline & & $\begin{array}{l}\text { skin } \\
1 \text { blended sample } \\
\text { of } 7 \mathrm{fish}\end{array}$ & $\frac{0.002}{0.012}$ & & \\
\hline
\end{tabular}


Table 1. Cont.:

\begin{tabular}{|c|c|c|c|c|c|}
\hline \multirow[t]{2}{*}{$\begin{array}{l}\text { Sampling } \\
\text { Date }\end{array}$} & \multirow[t]{2}{*}{$\begin{array}{l}\text { Time After } \\
\text { Bath }\end{array}$} & \multirow[t]{2}{*}{$\begin{array}{l}\text { Tissue } \\
\text { Sample Data }\end{array}$} & \multicolumn{2}{|c|}{ Sum of $\frac{\text { Coloured Form }}{\text { Malachite Green }}$} & \multirow{2}{*}{$\begin{array}{l}\text { Stat istical } \\
\text { Signif icance } \\
\text { of Difference } \\
\text { at } P<0.05\end{array}$} \\
\hline & & & $\begin{array}{l}x \pm s_{y_{1}} \\
(\mathrm{mg} \cdot \mathrm{kg})\end{array}$ & $\begin{array}{l}\min -\max \\
\left(\operatorname{mg} \cdot \mathrm{kg}^{-1}\right)\end{array}$ & \\
\hline \multirow[t]{3}{*}{16.3 .94} & \multirow[t]{3}{*}{$\begin{array}{l}8 \text { months } \\
\text { af ter bath }\end{array}$} & $\begin{array}{l}\text { muscle } \\
6 \text { samples } \\
\text { of } 6 \mathrm{fish}\end{array}$ & $\frac{<0.001}{0.0285 \pm 0.0144}$ & $0.013-0.047$ & \multirow[t]{3}{*}{$\stackrel{2}{4}<$} \\
\hline & & $\begin{array}{l}\text { liver } \\
1 \text { blended sample } \\
\text { of } 6 \mathrm{fish}\end{array}$ & $\frac{<0.001}{<0.005}$ & & \\
\hline & & $\begin{array}{l}\text { skin } \\
1 \text { blended sample } \\
\text { of } 6 \mathrm{fish}\end{array}$ & $\frac{<0.001}{0.01}$ & & \\
\hline \multirow[t]{3}{*}{21.4 .94} & \multirow[t]{3}{*}{$\begin{array}{l}9 \text { months } \\
\text { af ter bath }\end{array}$} & $\begin{array}{l}\text { muscle } \\
6 \text { samples } \\
\text { of } 6 \mathrm{fish}\end{array}$ & $\frac{<0.001}{0.0108 \pm 0.0154}$ & $0-0.039$ & \\
\hline & & $\begin{array}{l}\text { liver } \\
1 \text { blended sample } \\
\text { of } 6 \mathrm{fish}\end{array}$ & $\frac{<0.001}{<0.005}$ & & \\
\hline & & $\begin{array}{l}\text { skin } \\
1 \text { blended sample } \\
\text { of } 6 \mathrm{fish}\end{array}$ & $\frac{<0.001}{<0.005}$ & & \\
\hline \multirow[t]{3}{*}{25.5 .94} & \multirow[t]{3}{*}{$\begin{array}{l}10 \text { months } \\
\text { after bath }\end{array}$} & $\begin{array}{l}\text { muscle } \\
7 \text { samples } \\
\text { of } 7 \text { fish }\end{array}$ & $\frac{<0.001}{0.00243 \pm 0.00461}$ & $0-0.012$ & \multirow[t]{3}{*}{$<<$} \\
\hline & & $\begin{array}{l}\text { liver } \\
1 \text { blended sample } \\
\text { of } 7 \mathrm{fish}\end{array}$ & $\frac{<0.001}{<0.005}$ & & \\
\hline & & $\begin{array}{l}\text { skin } \\
1 \text { blended sample } \\
\text { of } 7 \mathrm{fish}\end{array}$ & $\frac{<0.001}{<0.005}$ & & \\
\hline \multirow[t]{3}{*}{26.7 .94} & \multirow[t]{3}{*}{$\begin{array}{l}12 \text { months } \\
\text { af ter bath }\end{array}$} & $\begin{array}{l}\text { muscle } \\
7 \text { samples } \\
\text { of } 7 \text { fish }\end{array}$ & $\frac{<0.001}{<0.005}$ & & \\
\hline & & $\begin{array}{l}\text { liver } \\
1 \text { blended sample } \\
\text { of } 7 \mathrm{fish}\end{array}$ & $\frac{<0.001}{<0.005}$ & & \\
\hline & & $\begin{array}{l}\text { skin } \\
1 \text { blended sample } \\
\text { of } 7 \mathrm{fish}\end{array}$ & $\frac{<0.001}{<0.005}$ & & \\
\hline
\end{tabular}


a liver sample where the amount of malachite green was beyond the limit of detection $(<$ $0.005 \mathrm{mg} \cdot \mathrm{kg}^{-1}$ ). Analyses of the following samples ( 9 months after the bath) were positive in 4 of 9 cases. An isolated detection of malachite green in muscle was still registered 10 months after the bath. In 12 months all sample analyses were negative and the experiment was terminated.

Residues of malachite green in marketable rainbow trout from selected fish farms in the Czech Republic

Random sampling for hygienic quality of marketable rainbow trout from the point of view of their contamination with malachite green provided the following results:

Analyses of tissues of marketable rainbow trout from 3 trout farms were found negative in 1993; in those of another trout farm there was a detection of malachite green in a "blended"skin sample slightly above the hygiene limit $\left(0.013 \mathrm{mg} \cdot \mathrm{kg}^{-1}\right)$. In tissues of fish from another trout farm increased values of malachite green residues were found. The sum of malachite green in muscle ranged in $0.017-0.079 \mathrm{mg} \cdot \mathrm{kg}^{-1}$, value detected in skin was $0.072 \mathrm{mg} \cdot \mathrm{kg}^{-1}$. Coloured form of malachite green was not proved.

Random sampling performed on 7 trout farms in 1995 did not show any defects, all sample analyses were found negative.

\section{Discussion}

The total content of malachite green in muscle, liver and skin of rainbow trout registered immediately after a long-term bath corresponded relatively well with data reported by Clift on-Hadley and Alderman (1987). These authors proved after short-term baths of rainbow trout in malachite green at $0.15,1.0$ and $1.5 \mathrm{mg} . \mathrm{l}^{-1}$ concentrations levels of 0.4 $\mathrm{mg} . \mathrm{kg}^{-1}, 1.2 \mathrm{mg} \cdot \mathrm{kg}^{-1}$ and $4.1 \mathrm{mg} . \mathrm{kg}^{-1}$ malachite green in the respective tissues. Its content in fish tissues was increased more when using repeated baths. Similarly, B a u e r et al. (1988) found during routine investigations that muscle of rainbow trout contained even up to 2.7 mg.kg-1 malachite green after baths performed. These authors further reported that about $90 \%$ of malachite green was cumulated in fish muscle as a leukobasis.

It resulted from our investigations that immediately after the bath $30 \%$ to $60 \%$ of total malachite green content was deposited in fish tissues in coloured form. In correspondence with literature the proportion of coloured form of malachite green in tissues of treated fish decreased rapidly.

On the other hand, the leukoform of malachite green persisted in fish tissues for a very long time and its decrease beyond the limit of detection was registered one year after the bath had been performed. This result also corresponds well with data of B a u er et al. (1988). These authors dealt in particular with kinetics of malachite green excretion from the body of treated fish. They reported that the time necessary to reach the food hygiene limit of malachite green content in tissues of the treated fish was related not only to the initial malachite green concentration in the fish body but also to their growth rate. This was the reason why fish mean body mass was recorded during our observations (Fig. 2). B a u e $\mathrm{r}$ et al. (1988) reported that in marketable fish with initial malachite green content $2 \mathrm{mg} \cdot \mathrm{kg}^{-1}$ this content would decrease to $0.010 \mathrm{mg} . \mathrm{kg}^{-1}$ in 331 days. This corresponds very well with our results.

It is interesting that during an examination carried out 6 months after the bath, the coloured form was detected in muscle of 2 from 7 samples analyzed in amount of $0.01 \mathrm{mg} . \mathrm{kg}^{-1}$ while 8 weeks after the bath no coloured form was detected in fish muscle at all. It could be explained by possible oxidation of uncoloured leukoform of malachite green during storage. 


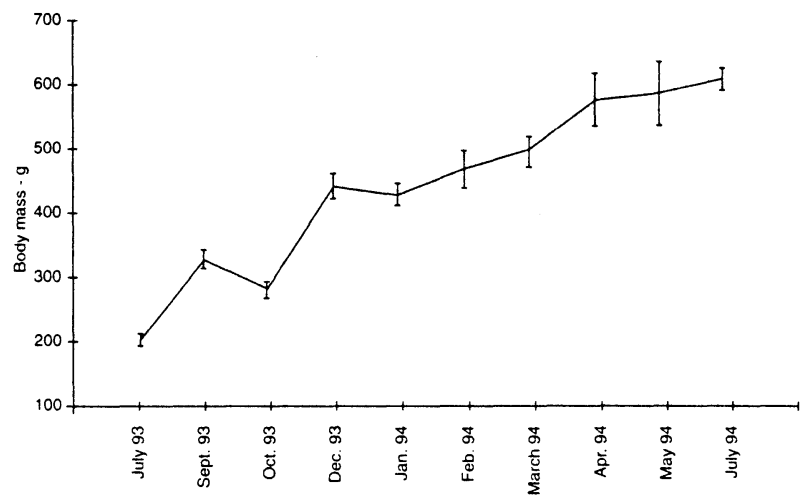

Fig. 2: Mean body mass of fish in the course of the experiment ( $g \pm$ S.D.).
This effect was observed by Poe and Wilson (1983), reporting that frozen tissue samples of channel catfish treated with malachite green have gained greenish colour after certain time of storage. In relation to the kind of bath performed, colouration of visceral fat occurred after 13-60 days and of muscle after 21-60 days. Our tissue samples were taken consequently, stored and analyzed after several samplings at once. For this reason the duration of storage was not the same for all samples. We therefore suppose that the re-appearance of coloured form of malachite green in samples could be due to oxidation of a part of malachite green leukoform.

Results obtained in correspondence with literature show that a 6-month withdrawal time since the fish bath until their distribution for consumption is not sufficiently long. The results indicated that this period was approximately one half of that in which the malachite green content really dropped below food hygiene limit valid in the Federal Republic of Germany. This fact led us to carry out several random samplings of sold rainbow trouts for food hygiene quality of their flesh from the point of view of malachite green contamination.

Checking performed in 1993 proved only an isolated finding of malachite green leukoform in marketable rainbow trout; all investigations in 1995 were found negative. This fact reports on minimum use of malachite green with trout of older categories. Introduction of a food hygiene limit of malachite green content in fish is therefore currently not taken into account. Nevertheless, its content in fish will be further observed.

It resulted from our investigations that malachite green persisted in treated fish as a leukoform for 10 months. In case of the frequent one-and-half-year-long productive cycle of rainbow trout we therefore did not recommend to carry out therapeutic baths in malachite green in fish older than 6 months.

\section{Přetrvávání malachitové zeleně v tkáních pstruha duhového po dlouhodobé léčebné koupeli}

Cílem naší práce bylo prověřit dobu pretrvávání malachitové zeleně u pstruhủ duhových po dlouhodobé koupeli a namátkovými kontrolami posoudit kvalitu tržních pstruhủ duhových z hlediska reziduí tohoto preparátu. Za tím účelem byla provedena šestidenní léčebná koupel pstruha duhového v malachitové zeleni o koncentraci $0.2 \mathrm{mg} \cdot \mathrm{l}^{-1}$. Následně byla sledována rezidua tohoto preparátu ve svalovině, játrech a kủži ošetřených ryb. Bezprostředně po koupeli bylo zjištěno ve svalovině $0.712 \pm 0.383 \mathrm{mg} . \mathrm{kg}^{-1}, \mathrm{v}$ játrech $0.834 \mathrm{mg} \cdot \mathrm{kg}^{-1}$ a v kůži $0.649 \mathrm{mg} \cdot \mathrm{kg}^{-1}$ malachitové zeleně, vyjádřené jako suma barevné formy a leukoformy. Po uplynutí 8 týdnů od provedené koupele byl zaznamenán výrazný pokles barevné formy malachitové zeleně, naproti tomu leukoforma byla detekována $v$ těle ryb ještě po uplynutí 10 měsícủ. Po uplynutí 12 měsíců od provedené koupele byly výsledky analýz negativní. Namátkové kontroly obsahu malachitové zeleně u tržních pstruhů duhových byly provedeny v průběhu let 1993 až 1995 na 12 pstruhařstvích ČR. Ve dvou případech byl nález mala- 
chitové zeleně pozitivní ( $z$ toho v jednom případě pouze mírně zvýšená hodnota v kůži), $\mathrm{v}$ ostatních př́ipadech byly výsledky analýz negativní. Z uvedených výsledků vyplývá, že malachitová zeleň v ošetřených rybách přetrvávává ve formě leukoformy po dobu 10 měsíců. Z toho je zrejmé, že v ČR doporučovaná šestiměsíční ochranná lhůta není dostačující. Proto při běžném jedenapůlletém výrobním cyklu pstruha duhového nedoporučujeme provádět léčebné koupele v malachitové zeleni ryb starších 6 měsíců.

\section{Acknowledgement}

This research was supported as Project No. 4013 by the National Agency for Agricultural Research. Ministry of Agriculture of the Czech Republic.

\section{References}

ALDERMAN. D. J. 1985: Malachite green: a review. J. Fish Diseases 8: 289-298

ALDERMAN. D. J.. CLIFTON-HADLEY.R. S. 1993: Malachite green: a pharmacokinetic study in rainbow trout, Oncorhynchus mykiss (Walbaum). J. Fish Diseases, 16: 297-311

ANTYCHOWICZ. J., ROGULSKA. A. 1985: Badania nad zwalczaniem kulorzeska (Ichthyophthirius multifiliis Fouguet. 1876) u karpi. Med. Wet. 41: 249-272

BAILEY. T. A. 1984: Effects of twenty-five compounds on four species of aquatic fungi (Saprolegniales) pathogenic to fish. Aquaculture 38: 97-104

BAUER. K.. DANGSCHAT. H., KNÖPPLER. H.-O., NEUDEGGER. J. 1988: Aufnahme und Ausscheidung von Malachitgrün bei Regenbogeforellen. Arch. f. Lebensmittelhygiene 39: 85-108

BASTIA W AN. D. 1986: Pengaruh malachite green oxalate terhadap infeksi jamur Saprolegnia pada telur ikan mas. Bull. Penel. Perik. Darat 5: 62-64

CLIFTON-HADLEY, R. S.. ALDERMAN. D. J. 1987: The effects of malachite green upon proliferative kidney disease. J. Fish Diseases 10: 101-107

EIMEN. S. 1989: Literaturstudie zur Verwendung von Malachitgrün und Formalin als Fischtherapeutika. Inaugural - Dissertation. Ludwig - Maximilians - Universität München, 317 pp.

FOSTER. F..J.. WOODBURY. L. 1936: The use of malachite green as a fish fungicide and antiseptic. Prog. Fish. Cult. 3: 7-9

JENEY, G.. JENEY.Z., OLÁH, J. 1979: A harcsaivadék formalin-, malachitzöld-, és antibiotikum- érzékenysége. Halászat 25: 24-25

KEYL. H.. G.. WERTH. G. 1959: Strukturveränderungen an Chromosomen durch Malachitgrün. Naturwissenschaften 46: 153-154

LANZING, W. J. R. 1965: Observations on malachite green in relation to its application to fish diseases. Hydrobiologia 25: 426-441

LUCKÝ. Z. 1978: Veterinární péěe v chovech ryb. Pardubice. Ústav veterinární osvěty, $205 \mathrm{~s}$.

MÁCHOVÁ. J.. SVOBODOVÁ. Z. 1984: Evaluation of four types of malachite green as to acute toxicity to fish. Práce VÚRH Vodñany 13,41-49

MEYER. F. P.. JORGENSON. T. A. 1983: Teratological and other effects of malachite green on development of rainbow trout and habbits. Trans. Amer. Fish. Soc. 112:818-824

NOGA, E. J. 1995: Fish Disease: Diagnosis and Treatment. Mosby, St. Louis, 367 pp.

POE, W. E.. WILSON, R. P. 1983: Absorption of malachite green by channel catfish. Prog. Fish. Cult. 45: 228-229

RAPP, J. 1995: Treatment of rainbow trout (Oncorhynchus mykiss Walb.) fry infected with Ichthyophthirius multifiliis) by oral administration of dimetridazole. Bull. Eur. Ass. Fish. Pathol. 15: 67-69

RYDLO. M. 1990: Current trends in fish therapy. Öster. Fisch. 43: 55-59

ŘEHULKA, J. 1977: Použití, snášenlivost a toxicita dlouhodobé koupele v malachitové zeleni B pro podzimní kapř́i plůdek. Živočiš. Výroba 22: 711-720

SCOTT, P. 1982: Chemical diseases control. Fish Farmer 5:35

SCHMAHL. G.. TARASCHEWSKI, H., MEHLHORN, H. 1989: Chemotherapy of fish parasites. Parasitol. Res. 75: 503-511

SCHMIDT, H., BRAUNBOOK, T.. RITTER. G., SCHMAHL, G., MEHLHORN, H. 1995: Control of protozoan diseases of fish by the administration of a medicated food containing quinine. EAFP, Seventh International Conference ..Diseases of Fish and Shellfish", Palma de Mallorca, 1 p.

STEFFENS, W., LEIDER, U., WEHRING. D., HATTOP, W. H. 1961: Möglichkeiten und Gefahren der Anwendung von Malachitgrün in der Fischerei. Z. Fisch. 10: 745-771

STUDNICKA, M., NIEZGODA, J., PROST, M. 1975: Porównanie toksycznosci blekitu metylenowego i zieleni malachitowej dla narybku pstraga teczovego. Med. Wet. 31: 226-229

SUMARI, O., VIRTANEN, H., SOIVIO, A. 1979: Formaliini-, suola-, malakiittivihreä-ja kaliumpermanganaattihoidon vaikutuksesta taimenen (Salmo trutta L.) kasvuum ja kuntoon. Suomen kalatalous 49:1-8 
SVOBODOVÁ, Z., MÁCHOVÁ, J., VYKUSOVÁ, B. 1995: Testing the possibility of treatment of different fish species infected with Ichthyophthirius multifiliis. EAFP, Seventh International Conference „Diseases of Fish and Shellfish", Palma de Mallorca, $1 \mathrm{p}$.

VYKUSOVÁ, B., SVOBODOVÁ, Z. 1986: Preventivní a léčebné koupele jiker (přehled). In: Reprodukce a genetika ryb, Vodňany, Slov. zool. spol., ichtyol. sekce, 125-131.

WERTH, G. 1958: Die Erzeugung von Störungen im Ergetüge und Tumoren durch experimentelle Gewebsanoxie. Arzneimittel-Forschung 8: $735-744$

WILLFORD, W. A. 1966: Toxicity of 22 therapeutic compounds to six fishes. In: Investigations in Fish Control, Washington, U.S. Dept. Interior, Fish and Wildl. Serv., No. 18: 3-10 